\title{
"Sunset and Evening Star"
}

IT REMAINS to record the slow-moving events of the final years of The Comstocks of Cornell.

On August 5, 1926, Professor Comstock had a strange sickness. The next day the "cruel blow" became evident,lyzed on his left side. The attack, more serious than at first realized, was the prelude to successive hemorrhages of the brain during the next four and one-half years which affected him in a progressively vital manner. After the first shock had spent itself, he rallied sufficiently to leave his bed and with the aid of a nurse to walk about his room and to take short rides, on propitious days.

Early in 1927 he became worse, and in June was again confined to his bed in a sleepy, listless condition. Following this shock, he lost the faculty of speech and became practically helpless. Nevertheless, he remained alert mentally and seemed to understand what was said to him. He did not seem to suffer pain. This condition continued during the next four years, until the final shock that quickly resulted in his death, on the morning of March 20, 1931.

In Mrs. Comstock's diary in July, 1926, she spoke for the first time of her "fibrillating heart." Thereafter, she frequently spoke of being tired and languid. Early in 1927 , she felt worse and her blood pressure became abnormally high, but she "must be doing," she "cannot sit still and think." She confided to her diary, "Strange days these,-the struggle on my part to self-control." Through all of the next three and one-half years of her husband's invalidism she maintained her round of activities, attending 
functions, often speaking in public and teaching in the Cornell University Summer Sessions. However, she grew slowly worse and through 1929 and 1930 was obliged to spend many hours in bed.

On June, 1930, Hobart College honored her with the degree of Doctor of Humane Letters. By reason of her indomitable will, and in spite of her physical condition, she made the trip to Geneva to be present at the conferring of the degree. She did not improve as the days wore on, yet she managed to guide her husband's care, to interpret his wishes, to give him her inspiring companionship, and to carry her work of teaching through the Summer Session of 1930. She even received her class in her home, at the close of the term, about the middle of August. Less than two weeks thereafter, on Sunday morning, August 24, 1930, she died as bravely as she had lived.

The ashes of each rest in Lakeview Cemetery, in Ithaca, beneath some fine oaks on a high knoll facing the west. The site overlooks the valley below with Lake Cayuga winding away to the horizon, a scene they had loved and enjoyed together through all of their years at Cornell.

GlenN W. Herrick 